\title{
Carnegie Libraries in New Jersey: 1900-1923
}

\section{By Eleonora Dubicki}

\section{DOI: http://dx.doi.org/10.14713/njs.v3i2.85}

A free public library is the cornerstone of most American communities. Libraries offer a variety of far-reaching services, ranging from books for self-education and leisure reading, to informational and cultural programs. Carnegie libraries constructed in the early 1900s through the philanthropy of Andrew Carnegie played a significant role in transforming the library movement from subscription libraries for special interest groups to free public libraries with services accessible by all. Of the 1,412 communities in the United States to build Carnegie libraries, twenty-nine communities in New Jersey benefitted from this program. ${ }^{l}$ This research project draws primarily on original correspondence between New Jersey communities seeking library building funds and Andrew Carnegie. The letters supporting funding applications create a unique demographic and economic snapshot of New Jersey communities during the early 1900s when the Carnegie libraries were erected in the state. This study offers historical insights and informs the role that the Carnegie libraries played in their respective communities.

\section{Early History of New Jersey Libraries}

Public libraries were first established in New Jersey during the mid-eighteenth century. Known as "library companies or societies," the earliest libraries were formed in Trenton (1750), Elizabeth (1755), and Burlington (1758). ${ }^{2}$ Although company or society libraries were open to the public, they were typically known as subscription libraries because they required members to pay a membership fee to join and subsequent annual fees. Since few working class families could

\footnotetext{
${ }^{1}$ George S. Bobinski, Carnegie Libraries: Their History and Impact on American Public Library Development (Chicago, IL: American Library Association, 1969), 3, 19.

${ }^{2}$ Roger McDonough, "Public Libraries," in A History of New Jersey Libraries 1750-1996, ed. Edwin Beckerman (Lanham, MD: The Scarecrow Press, 1997), 1.
} 
afford to pay fees, members were primarily wealthy and educated individuals in the community, including lawyers, clergy, and property owners. The library collections closely reflected the interests of the membership of the societies and were often housed in private homes. By 1800, twenty-one New Jersey municipalities had one or more libraries. ${ }^{3}$

In the early nineteenth century, New Jersey began to transition from an agricultural to an industrial-based economy. The library movement in the state also shifted from the elite society libraries to "apprentice libraries" to meet the needs of a growing working class. The apprentice libraries provided young men working as mechanics or tradesmen with vocational reading materials, as well as resources to help them improve their position in society. Newark and Trenton opened the first apprentice libraries in 1821, closely followed by Burlington (1822) and Elizabeth (1825). ${ }^{4}$ Frequently housed in rented rooms, the libraries were usually run by volunteers and open only a few hours a week.

By the mid-nineteenth century, fifty-seven libraries were operating in New Jersey. ${ }^{5}$ In contrast to the society and apprentice libraries that served specific groups, the new public libraries offered collections that were of interest to the general population. During the Progressive era there was widespread social activism, political reform, and a focus on public education, including selfeducation facilitated by access to books in public libraries. New Jersey Library Laws were passed in 1884 and 1905, setting the stage for communities to vote on referendums to support free public libraries through municipal appropriation of one-third of a mill property tax on every dollar of assessed valuation that would cover the cost of book purchases, employee salaries, and general maintenance of the buildings.

\footnotetext{
${ }^{3}$ Ibid.

${ }^{4}$ Ibid, 5 .

${ }^{5}$ Ibid, 8.
} 
Rapid growth in the fledgling public library movement created a demand for experienced librarians and library staff. The New Jersey Library Association (NJLA) was founded in 1890, and a decade later the Public Library Commission (PLC) was established by the state legislature to provide support to public libraries. Under the leadership of Miss Sarah Byrd Askew, one of the key objectives of the PLC was to meet with community leaders to encourage them to establish and support free public libraries in their towns. Miss Askew worked tirelessly to extend library services to all New Jersey residents. In its Second Annual Report (1901), the PLC noted that there were 102 New Jersey libraries, including fifty-two free public libraries and thirty-eight subscription libraries. ${ }^{6}$ Because of Askew's efforts during the first two decades of the twentieth century, which coincided with the height of Carnegie Library construction, the number of public libraries in New Jersey increased to three hundred and twenty-five by $1920 .^{7}$ In the sparsely populated southern part of New Jersey, a traveling libraries program was introduced. Isolated rural communities received cases holding approximately fifty books that were often housed in Granges, schools, and town halls for use by local neighborhoods. The traveling library program grew quickly during the two decades as well, reaching six hundred and ninety-one stations in 1,572 communities serving an aggregate population of 217,300 by $1920 .^{8}$

Supplementary support for libraries was provided by NJLA and the PLC by convening annual conferences and sponsoring summer schools for librarians. Classes and lectures were held in the Asbury Park Library for the benefit of those in charge of very small libraries with limited funds, and whose librarians lacked special training. Coursework consisted of instruction in

\footnotetext{
${ }^{6}$ Public Library Commission of the State of New Jersey, Second Annual Report of the Public Library Commission of the State of New Jersey (Trenton, NJ: John J. Murphy Pub. Co. 1901), 6.

${ }^{7}$ Roger McDonough, "Public Libraries," in A History of New Jersey Libraries 1750-1996, ed. Edwin Beckerman (Lanham, MD: The Scarecrow Press, 1997), 13.

${ }^{8}$ Public Library Commission of the State of New Jersey, Twenty-first Annual Report of the Public Library Commission of the State of New Jersey (Trenton, NJ: John J. Murphy Pub. Co. 1920), 21.
} 
selecting and buying books, classification, cataloging, reference work, and general administration. ${ }^{9}$ Furthermore, guidance in collection development was provided to librarians with a list of the recommended first thousand books for a library published in the appendix to the PLC's $3^{\text {rd }}$ Annual Report. The breadth of suggested subjects for public library collections included: general works, history, biography, natural sciences, technology and sport, art and music, myths and legends, economics, politics, education, conduct and culture, English language, literature, poetry, and fiction. ${ }^{10}$ In subsequent years, PLC annual reports and the New Jersey Library Bulletin regularly included suggestions for new books.

At the turn of the century, public libraries were frequently located in rooms in schools or municipal buildings. As communities grew, municipalities reclaimed these spaces for classrooms and offices, often resulting in multiple relocations of libraries. A permanent solution was needed for libraries to be housed in their own buildings. Unfortunately, the cost of purchasing a site and constructing a library building was a formidable financial obstacle for many municipalities. As suburban populations grew rapidly, municipalities were faced with significant expenditures to improve public infrastructure, such as roads and sewers, as well as constructing schools to educate the children, leaving limited funds for libraries. Andrew Carnegie, the Scottish-born industrialist, made a significant impact on the evolution of the free public library movement in the United States when he began offering funds to municipalities that might otherwise have been unable to raise the money to erect library buildings.

\footnotetext{
${ }^{9}$ Public Library Commission of the State of New Jersey. Seventh Annual Report of the Public Library Commission of the State of New Jersey (Trenton, NJ: John J. Murphy Pub. Co., 1906), 7-8.

${ }^{10}$ Public Library Commission of the State of New Jersey. Third Annual Report of the Public Library Commission of the State of New Jersey (Trenton, NJ: John J. Murphy Pub. Co., 1902), Appendix.
} 


\section{Carnegie's Support of Libraries}

Andrew Carnegie was born on November 25, 1835 in Dunfermline, Scotland. His family immigrated to America in 1848, settling in the Pittsburgh, Pennsylvania area. Carnegie began working at the age of thirteen, employed in a variety of jobs including: bobbin boy, telegraph messenger, telegraph operator, and positions of increasing responsibility in railroads, oil, iron and steel. His limited formal education was supplemented by reading and self-study. In his autobiography, Carnegie discusses the benefits he gained when Colonel James Anderson opened his private library of 400 volumes to young working boys: "Books which it would have been impossible for me to obtain elsewhere were, by his wise generosity, placed within my reach; and to him I owe a taste for literature which I would not exchange for all the millions that were ever amassed by man."11

After accumulating a fortune in the steel industry, Carnegie sold his business to J.P. Morgan in 1901 and focused on philanthropy, where his early experiences with books influenced his interest in free public libraries. He envisioned libraries as centers for self-improvement, where anyone with the desire could educate themselves. From his own experience Carnegie decided, "there was no use to which money could be applied so productive of good to boys and girls who have good within them and ability and ambition to develop it, as the founding of a public library in a community which is willing to support it as a municipal institution."12

Carnegie spent over \$56 million to fund 2,509 libraries in English-speaking countries worldwide between 1881 and 1917. In the United States, 1,412 communities received funding for 1,679 libraries, including \$1,066,935 in twenty-nine New Jersey communities. New Jersey ranked eleventh, in terms of the total number of communities receiving grants. Indiana received the most

\footnotetext{
${ }^{11}$ Andrew Carnegie, Autobiography of Andrew Carnegie (Boston, MA: Houghton Mifflin, 1920), 46.

12 Ibid, 47.
} 
grants for one hundred and fifty-six communities. In fact, the Midwest (Ohio to the Dakotas) received sixty-one percent of all Carnegie grants. The Northeast, including New Jersey, already had a significant number of existing public libraries during the time of Carnegie grants and received only fourteen percent of total grants. ${ }^{13}$

The process for obtaining building grants was straightforward, but often was not easy. Formal requests and correspondence regarding library grants were initially directed to Andrew Carnegie. ${ }^{14}$ In 1911, Carnegie created the Carnegie Corporation of New York (CCNY) to manage his philanthropic interests. The requests were administered by James Bertram, Carnegie's personal secretary and later secretary of CCNY. Basic information that was required included: name and population of the city, details on the current library (books, circulation, location, and finances), the amount pledged from taxation to support library, availability of a site, and amount of funds collected for building.

After a review of the application questionnaire and Andrew Carnegie's approval, Bertram sent a letter to the town offering a specific grant amount based primarily on the population of the community at about $\$ 2$ per resident. ${ }^{15}$ The letter also defined the specific conditions that needed to be met, including a resolution from the Board of Commissioners to maintain the library at a cost of ten percent of the grant amount annually and that the municipality provide a suitable building

\footnotetext{
${ }^{13}$ George S. Bobinski, Carnegie Libraries, 3,17,19,20.

${ }^{14}$ All of the original correspondence regarding Carnegie public library grants has been microfilmed and is currently housed in Columbia University's Rare Book and Manuscript Library in New York City. The author was able to borrow microfilm through inter-library loan and reviewed materials for New Jersey municipalities. Arranged alphabetically, the 40 reels of microfilm contain applications, letters, newspaper clippings, and other materials submitted by municipalities seeking funding, as well as responses from James Bertram regarding applications. Files are primarily typewritten letters, but also include some barely legible handwritten notes. The material used in this manuscript is cited: Carnegie Corporation of New York Records. Rare Book and Manuscript Library. Columbia University Libraries. Series II. Files on Microfilm, ca 1886-1977. Gifts and grants. Libraries. Free Public Library Buildings. (hereafter cited as CCNY Records). Citations in footnotes also give the name of the municipality and microfilm roll number. This type of citation indicates that information was obtained from many sources on one community. If information was obtained from a specific letter or document, these are cited in detail.

${ }^{15}$ Theodore Jones, Carnegie Libraries Across America: A Public Legacy (NY: John Wiley \& Sons, 1997), 28.
} 
site. Bertram approved funding and directed CCNY Treasurer Robert A. Franks to make the funds available to the communities once the conditions were met.

The style of the building was up to the community, but about seventy-five percent of Carnegie libraries reflected historical revival designs. ${ }^{16}$ James Bertram preferred library buildings that were practical and efficient in design and beginning in 1904 he required that building plans be approved before any expenditures were incurred. He would often ask for modifications such as height of ceilings, placement of windows, and elimination of fireplaces. To address problems that arose in estimating the appropriate size of the libraries, Bertram created "Notes on the Erection of Library Bildings" (stet) that provided communities with guidance on interior layouts. ${ }^{17}$

The Carnegie libraries had a pronounced impact on the free public library movement in serving the general population, both adults as well as children. Previously, society and apprentice libraries were primarily for educated men or trade workers and were housed in one room libraries. The Carnegie libraries featured an open plan which encouraged communication with the librarian, allowed patrons to freely browse the stacks of the collection, and included a meeting room for community use. Although architectural styles of the Carnegie libraries varied, many had stately pillars, triangular pediments, and an overall symmetry which made them easily recognizable as the town's public library. ${ }^{18}$ To improve accessibility for patrons, most Carnegie libraries were centrally located on the main thoroughfare in close proximity to other municipal structures.

\footnotetext{
16 Ibid, 61.

${ }^{17}$ James Bertram, Notes on the Erection of Library Bildings. (NY: CCNY, 1911). Bertram favored simplified spelling which sometimes looked like misspelled words in his correspondence, e.g. altho, hav, bildings, receiv. 18 Abigail Ayres Van Slyck, Free to All: Carnegie Libraries and American Culture 1890-1920. (Chicago, IL: University of Chicago Press, 1995), 34.
} 


\section{New Jersey Communities with Carnegie Libraries}

According to George Bobinski, twenty-nine communities in New Jersey received funding to erect thirty-five library buildings, twenty-nine main and six branch libraries. ${ }^{19}$ This number is somewhat contested by other researchers who cite thirty New Jersey communities and thirty-six buildings, including Orange, New Jersey which was granted $\$ 1,500$ for an unusual request to purchase an existing building to house a library. ${ }^{20}$ Five additional communities submitted applications for funding and were tentatively offered grants, but never built their Carnegie library buildings (Cape May, Dover, Paulsboro, Red Bank, and West Orange), primarily due to financial reasons. $^{21}$

One might wonder why more New Jersey communities did not apply for Carnegie funding. According to the U.S. Census of 1900, New Jersey was the sixteenth most populated state, with seven of the 100 major cities in the country. ${ }^{22}$ Of those large cities, five communities (Newark, Jersey City, Paterson, Trenton, Hoboken) were prosperous enough to finance library construction with funds raised by their library associations or private funding from local philanthropists. The fiscal difficulties faced by the large cities of Camden and Elizabeth, as well as Perth Amboy, were apparently a major factor in applying for Carnegie grants since the municipalities could not afford to fund construction of a library building independently. In most cases, towns sought Carnegie funding in response to a person championing the establishment of a public library or a Women's Club who urged their community officials to submit an application, but the town lacked funds to erect the library. Overall, most of New Jersey's rapidly growing suburban towns were able to pass

\footnotetext{
${ }^{19}$ Bobinski, Carnegie Libraries, 19, 20.

${ }^{20}$ Jones, Carnegie Libraries Across America, 129. Sharon Hazard, “A Gift that Keeps on Giving: NJ's Carnegie Libraries" New Jersey Monthly, April 8, 2013, accessed May 2017, https://njmonthly.com/articles/jersey-living/agift-that-keeps-on-giving/

${ }^{21}$ Bobinski, Carnegie Libraries, 115-142.

22 U.S. Bureau of Census, Table 13, Population of the 100 Largest Urban Places:1900, accessed May 2017 https://www.census.gov/population/www/documentation/twps0027/tab13.txt
} 
library law resolutions and subsequently finance both a library site and construction of a library without obtaining Carnegie funds. On the other hand, the communities in southern New Jersey were typically too small to meet the minimum population required for Carnegie applications, and the traveling library program run by the PLC fulfilled their library service needs.

Besides the financial condition of the cities, another factor affecting requests for Carnegie funding stemmed from concerns regarding his motivations. Some critics felt that his philanthropy was based on tainted funds earned at the expense of underpaid labor workers in his steel mills. Additionally, "His accusers claimed that he built libraries as monuments of himself for posterity." 23 In response to such criticism, Carnegie maintained that he provided a means to obtain the buildings, but it was the communities' responsibility to provide annual funding to stock the library with books, hire staff, and pay for general maintenance.

Carnegie libraries were erected in a diverse range of New Jersey communities as defined by demographic and economic characteristics: large cities (Camden, Elizabeth); agricultural communities (Caldwell, Freehold, Vineland); industrial working class communities (Bayonne, Belleville, Edgewater, Elizabeth, Kearny, New Brunswick, Perth Amboy, West Hoboken); suburban communities (Cranford, Collingswood, East Orange, Englewood, Lakewood, Little Falls, Montclair, Nutley, Plainfield, Summit, Union Hill, Verona, Westfield) and resort towns (Atlantic City, Avon-by-the-Sea, Belmar, Long Branch).

The applications and letters of correspondence with Carnegie provide detailed information about each community that requested funds. The letters reveal the nature of the community and explain why a new library building was needed. The correspondence also exposes the problems, confusion, and delays experienced by communities during the planning and construction process.

${ }^{23}$ Bobinski, Carnegie Libraries, 13. 
In order to create a snapshot of the communities receiving Carnegie library funding, microfilmed correspondence for each community was reviewed for this manuscript. Additional community information was acquired from PLC reports. Table 1 summarizes information on the Carnegie libraries built in New Jersey.

In terms of the amount of funding distributed, only three New Jersey communities (Camden, East Orange, Elizabeth) received more than $\$ 100,000$, and in each case this was for multiple library buildings. Six communities received funding between $\$ 50,000$ and $\$ 85,000$. Seventy percent of the funding for New Jersey Carnegie libraries was for less than $\$ 30,000$, closely reflecting the percentage of small communities receiving Carnegie funding throughout the United States. ${ }^{24}$ Requests made to CCNY for additional funds to meet higher than anticipated costs or for building additions to meet rapidly growing constituencies were not uncommon among New Jersey municipalities. Several communities received additional funding for expansions and branch libraries, including East Orange, Elizabeth, Bayonne, New Brunswick, and Perth Amboy. (Scroll for table)

\footnotetext{
${ }^{24}$ Bobinski, Carnegie Libraries, Appendix B.
} 
Table 1: New Jersey Carnegie Libraries

\begin{tabular}{|c|c|c|c|c|}
\hline Municipality & $\begin{array}{l}\text { Population } \\
(1900,1910)\end{array}$ & Initial Grant & Amount & Opened \\
\hline Atlantic City* & 27838 & $1 / 22 / 1903$ & $\$ 71,075$ & 1904 \\
\hline Avon-by-the-Sea & 707 & $5 / 15 / 1916$ & $\$ 5,000$ & 1917 \\
\hline Bayonne & 32722 & $4 / 13 / 1903$ & $\$ 83,000 * *$ & 1904 \\
\hline Belleville & 7500 & $4 / 28 / 1909$ & $\$ 20,000^{* * *}$ & 1911 \\
\hline Belmar & 1433 & 4/14/1914 & $\$ 13,000$ & 1914 \\
\hline Caldwell & 1600 & $1 / 8 / 1908$ & $\$ 10,000 * *$ & 1917 \\
\hline Camden (3)* & 75935 & $1 / 2 / 1903$ & $\$ 120,000$ & 1905 \\
\hline Collingswood* & 4795 & $1 / 5 / 1916$ & $\$ 15,000$ & 1918 \\
\hline Cranford* & 4000 & $1 / 20 / 1908$ & $\$ 10,000$ & 1910 \\
\hline East Orange (3)* & 25000 & $1 / 8 / 1900$ & $\$ 116,000^{* * *}$ & 1903 \\
\hline Edgewater & 2655 & $3 / 16 / 1915$ & $\$ 15,000$ & 1916 \\
\hline Elizabeth (2) & 60509 & $2 / 3 / 1910$ & $\$ 130,810^{* *}$ & 1912 \\
\hline Englewood* & 9924 & $7 / 9 / 1913$ & $\$ 25,000$ & 1915 \\
\hline Freehold & 2932 & $3 / 27 / 1903$ & $\$ 11,000 * *$ & 1904 \\
\hline Kearny & 13600 & $1 / 16 / 1906$ & $\$ 27,600$ & 1907 \\
\hline Lakewood* & 5149 & $2 / 3 / 1917$ & $\$ 12,500$ & 1918 \\
\hline Little Falls* & 3750 & $4 / 3 / 1917$ & $\$ 10,000$ & 1918 \\
\hline Long Branch & 13298 & $2 / 3 / 1917$ & $\$ 30,000$ & 1920 \\
\hline Montclair (2) & 14000 & $3 / 8 / 1901$ & $\$ 60,000$ & 1904 \\
\hline
\end{tabular}




\begin{tabular}{|l|r|r|l|l|}
\hline New Brunswick & 20006 & $3 / 14 / 1902$ & $\$ 52,500 * *$ & 1903 \\
\hline Nutley & 6009 & $2 / 3 / 1913$ & $\$ 20,000$ & 1914 \\
\hline Perth Amboy & 17699 & $3 / 8 / 1901$ & $\$ 50,450 * *$ & 1903 \\
\hline Plainfield* & 15369 & $2 / 7 / 1911$ & $\$ 50,000$ & 1912 \\
\hline Summit* & 7500 & $2 / 1 / 1909$ & $\$ 21,000$ & 1911 \\
\hline Union Hill & 15187 & $2 / 5 / 1904$ & $\$ 25,000$ & 1905 \\
\hline Verona & 1675 & $3 / 31 / 1916$ & $\$ 11,000$ & 1923 \\
\hline Vineland* & 5000 & $2 / 2 / 1903$ & $\$ 12,000$ & 1904 \\
\hline West Hoboken & 23094 & $2 / 4 / 1902$ & $\$ 25,000$ & 1904 \\
\hline Westfield* & 5000 & $12 / 30 / 1904$ & $\$ 15,000$ & 1906 \\
\hline
\end{tabular}

* Carnegie building no longer serves as a library

** Multiple grants

\section{Communities Receiving over $\$ 100,000$}

East Orange was the first city in New Jersey to receive Carnegie funding (on January 18, 1900) for their main library. A handwritten letter from Louise Petersen, corresponding secretary of the East Orange High School Alumni Association, explained that East Orange needed their own library since its population of 25,000 was forced to use libraries in Orange and Newark. The site chosen for the library was in the rapidly growing eastern section of the town that had a population described as intelligent and desirable, yet without the means to possess their own books. ${ }^{25}$ The library opened on January 22, 1903.

\footnotetext{
25 Louise Peterson to Carnegie, 18 January 1900. CCNY Records. (East Orange, NJ, Carnegie Library Correspondence, Microfilm No. 9).
} 
Citing strong library usage, with close to fifty percent of the population being active borrowers, East Orange was successful in securing additional Carnegie funds for the expansion of the main library and the erection of two branch libraries in sections of the community that lacked public transportation. By 1914, the number of volumes loaned by the main library was nearly 223,000. According to librarian Louise Hinsdale, fiction accounted for $66.6 \%$ of book loans, although she saw a growing interest in poetry and drama. ${ }^{26}$ The library expansion led to the introduction of a new library program coordinated with local public schools. The reference librarian visited the eighth grade classes in five neighboring schools to deliver talks on the proper use of a library. Subsequently, the students visited the main library to complete assignments using the card catalog and then locating books in the library's collection. ${ }^{27}$
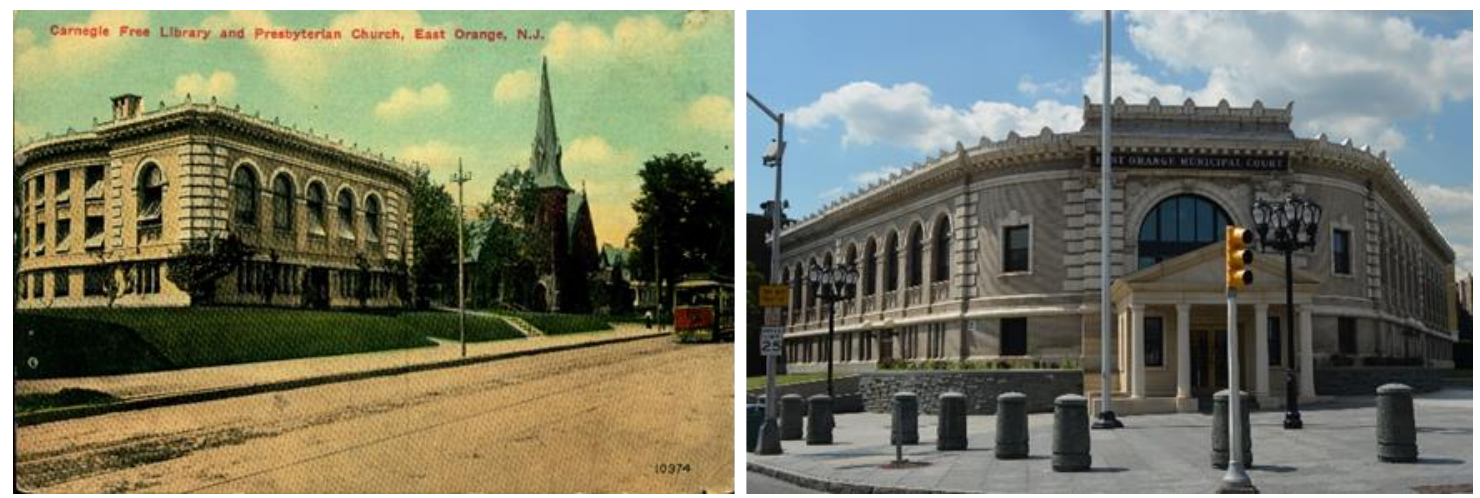

\section{Carnegie Library, East Orange, N.J. Postcard circa 1905 and photograph, 2014, from author's collection.}

Only two other New Jersey communities received over $\$ 100,000$ for library buildings, Camden and Elizabeth. Located across the Delaware River from Philadelphia, Camden had a population of almost 76,000 in 1900, having tripled in size in the prior twenty-five years according to Dowling

\footnotetext{
${ }^{26}$ Louise Hinsdale to Carnegie, 26 March 1914. CCNY Records. (East Orange, NJ, Carnegie Library Correspondence, Microfilm No. 9).

27 "Classes in the Library," New Jersey Library Bulletin 7, no.3 (1918): 8.
} 
Benjamin MD in his October 1902 application letter. ${ }^{28}$ Camden received funding of $\$ 100,000$ for the main library and $\$ 20,000$ for two branch libraries on January 6, 1903. The amount was increased in January 1905 by $\$ 20,000$ to complete the project. The neoclassical style main library designed by Herbert D. Hale and Henry G. Morse was built at the intersection of Broadway and Line Avenues on the Dialogue Property and was completed in $1905 .^{29}$

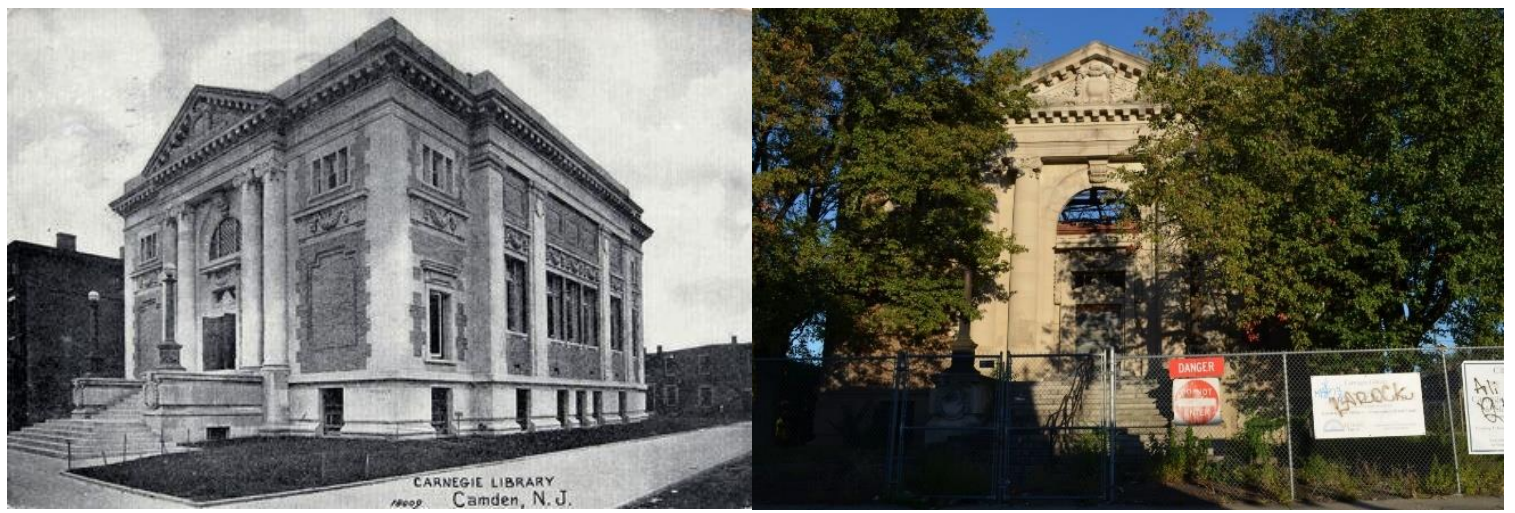

Carnegie Library, Camden, N.J. Postcard, circa 1905, and photograph, 2015, from author's collection.

The application submitted by Elizabeth in January 1910 reveals that the city had a library of 13,347 books that had outgrown its accommodations in a rented building that needed significant renovation. With a population of 73,409 in 1910 , Elizabeth was one of the largest cities in the state. It was described as two distinct sections about two miles apart, each needing different library services. Elizabeth proper, the center of most of the commercial and municipal activity, was the proposed location of the new main Carnegie Library. Elizabethport, the site of the Liberty Square branch library, was the manufacturing area tenanted by mechanics who worked in the Singer Manufacturing Company, Standard Oil plant, Stevenson Car Works, Central Railroad, and several

\footnotetext{
${ }^{28}$ Dowling Benjamin, MD to Carnegie, 24 October 1902. CCNY Records. (Camden, NJ, Carnegie Library Correspondence, Microfilm No. 5).

${ }^{29}$ CCNY Records. (Camden, NJ, Carnegie Library Correspondence, Microfilm No. 5).
} 
other large factories. ${ }^{30}$ The main library opened in 1912. Library director Charles A. George “believed that dissemination of ideas was a library's main function and when new media appeared that would serve that purpose he adopted them." ${ }^{31}$ His visionary ideas resulted in unique collections that were loaned out to patrons, including mounted prints, industrial exhibits, maps, and phonograph recordings of plays, speeches, stories, languages, and music.

\section{Agricultural Roots}

With the nickname the "Garden State," agriculture has played an important role in New Jersey's economy. According to the U.S. Census of 1900, 9.1\% of New Jersey's population was engaged in agriculture. ${ }^{32}$ Several towns in New Jersey that applied for Carnegie Library funding described themselves as farming communities (Freehold, Vineland, Caldwell).

Marion Laird, Secretary of the Library Auxiliary in Freehold, made the initial inquiry regarding funding in 1902 to replace a small subscription library of about 1,000 volumes established in Freehold by the King's Daughters, a society of young women. Laird described Freehold as having a population of about four thousand inhabitants in the midst of a farming community with comfortable homes but no wealth. She further explained that there was a need for a free public library to supplement the education delivered in the local schools. The King's Daughters had attempted to raise money for a new library building, but after months of hard work were only able to raise $\$ 769$. Thus, they contacted Carnegie for building funds, stating: "Should you feel your heart moved to help us, the long evenings in many a farmhouse near here would be

\footnotetext{
${ }^{30}$ Henry H. Isham to Carnegie, 11 February 1909. CCNY Records. (Elizabeth, NJ, Carnegie Library Correspondence, Microfilm No. 9).

${ }^{31}$ Lawrence Vezin and Ruth Dannefelser, A History of the Free Public Library of the City of Elizabeth (Elizabeth, NJ, 1972).

${ }^{32}$ U.S. Census Bureau, Census of Population and Housing, 1900 Census Documents, "Volume 2: Population Pt 2: Ages, School, Militia, and Voting Ages, Conjugal Condition, School Attendance, Illiteracy, Cannot Speak English, Occupations, Dwellings and Families, Proprietorship of Homes," accessed November 23, 2016, http://www.census.gov/prod/www/decennial.html
} 
shortened and the inspiration and impetus of good reading would come to many a factory boy and girl in our little town, years before we could give it to them."33

Carnegie offered Freehold \$10,000 on March 27, 1903 to build the library, which was later increased by $\$ 1000$ to finish the interior. The library was built on the Doty Lot on Main Street in the center of town. The Freehold library became the second Carnegie Library completed in New Jersey and was the only one with "Carnegie Library" etched over the entrance. ${ }^{34}$
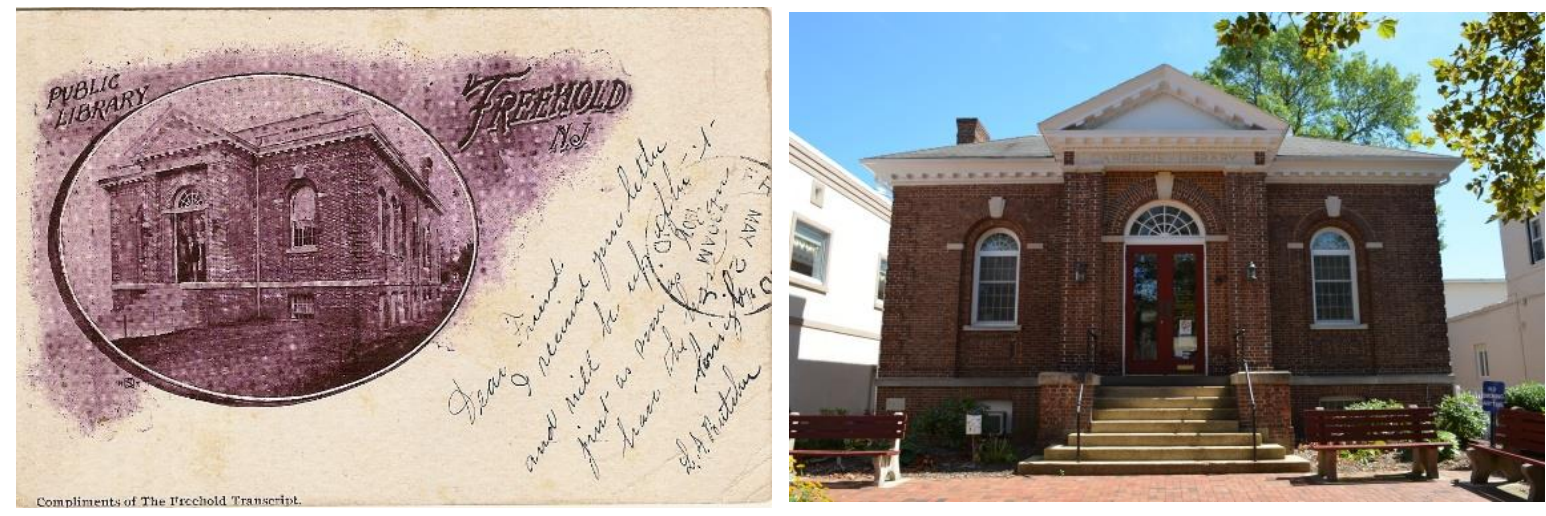

\section{Carnegie Library, Freehold, N.J. Postcard circa 1905 and photograph, 2014, from author's collection.}

The initial correspondence regarding a free public library for Vineland was a handwritten letter from Thomas W. Braidwood dated January 3, 1902. He noted that the settlement began as an agricultural community and some manufacturing was introduced in the municipality which was spread over thirty square miles. ${ }^{35}$ On February 3, 1903 Carnegie presented an offer of $\$ 12,000$ for the library building. In 1908, librarian Minnie Clark made an unsuccessful request for additional funds for a children's room to meet the needs of a growing immigrant population:

Vineland is an Immigrant Center; hundreds of Russian Jews and Italians have settled in the town and surrounding farms - they all have a generous share of the poor man's blessing these little ones are remarkably bright and take readily to the Public School and Library,

\footnotetext{
${ }^{33}$ Marion Laird to Carnegie, 26 February 1902. CCNY Records. (Freehold, NJ, Carnegie Library Correspondence, Microfilm No. 11).

${ }^{34}$ CCNY Records. (Freehold, NJ, Carnegie Library Correspondence, Microfilm No. 11).

35 Thomas W. Braidwood to Carnegie, 3 January 1902. CCNY Records. (Vineland, NJ, Carnegie Library Correspondence, Microfilm No. 33).
} 
where some of them will get all their education. They flock to the Childrens Room - at first they were noisy and disorderly, now they are quiet and full of interest - the books are read and re-read mended and rebound until they are hopeless and the cry is always for more and more. If we could only supply this demand and provide suitable chairs and tables, we feel that a powerful and far reaching work might be accomplished. ${ }^{36}$

In 1907, Edgar Williams described another agricultural community seeking a Carnegie library, "Caldwell is a fine old village, in the Orange Mountains, northwest of Montclair. It is the centre of a large farming section in the western and northwestern section of Essex County."37 Based on the facts in the application form, on January 8, 1908, Carnegie offered $\$ 7,500$ for a library building. Selection of an appropriate building site significantly delayed construction of the library. The initial proposal was to build the library on the Grover Cleveland Birthplace property, but it was deemed too distant from the center of town and the noise from the trolleys would be a disadvantage. Ultimately, the Provost site adjoining the public square was secured for the library in 1916 with private donations from George McCanfield and others. However, a review of the building plans and costs of the building found that it could not be completed for the amount promised, therefore a request was made to the Carnegie Corporation to increase the amount. On November 9, 1916 Bertram adjusted the amount to $\$ 10,000$. The library building was completed and the formal opening was held Friday evening, October $12^{\text {th }}, 1917$, with Sarah B. Askew of the New Jersey State Library Commission addressing the guests.

\section{Working Class Communities}

The growth of manufacturing, particularly in the northern section of the state, created a new group of patrons for public libraries, working class laborers, and immigrants. Much of this population had limited access to books and little discretionary income to support public libraries.

\footnotetext{
${ }^{36}$ Minnie Clark to Carnegie, 1 July 1908. CCNY Records. (Vineland, NJ, Carnegie Library Correspondence, Microfilm No. 33).

${ }^{37}$ Edgar Williams to Carnegie, 18 December 1907. CCNY Records. (Caldwell, NJ, Carnegie Library Correspondence, Microfilm No. 4).
} 
According to the 1900 U.S. Census, 40.4\% of New Jersey residents were engaged in manufacturing and mechanical jobs, with an additional $28.7 \%$ in trade and transportation. ${ }^{38}$ As the twentieth century began, yearly household income in the U.S. averaged $\$ 750$, with very little money available for non-necessities. ${ }^{39}$ The steady flow of immigrants arriving at ports in New York and New Jersey generated a new workforce for factories and had a significant community impact in terms of education. In $1900,22.9 \%$ of New Jersey's $1,480,498$ population was foreign born. This number was particularly high in New Jersey's principal cities, such as Bayonne where a third of the population were immigrants. ${ }^{40}$

Bayonne was one of the large New Jersey municipalities with a working class population heavily employed in manufacturing. In the April 1903 application letter, Bayonne was described as a city of 40,000 inhabitants, of whom an estimated 20,000 did not earn more than $\$ 12$ per week. Just a couple of weeks after the application was submitted, $\$ 50,000$ was offered by Andrew Carnegie for a library building. A Gothic-style library building was designed by Edward L. Tilton, and opened on October 29, 1904. A postcard of the library was printed to acknowledge the importance of the library to the community. ${ }^{41}$

\footnotetext{
${ }^{38}$ U.S. Census Bureau, Census of Population and Housing, 1900 Census Documents, "Volume 2: Population Pt 2: Ages, School, Militia, and Voting Ages, Conjugal Condition, School Attendance, Illiteracy, Cannot Speak English, Occupations, Dwellings and Families, Proprietorship of Homes," accessed November 23, 2016, http://www.census.gov/prod/www/decennial.html

${ }^{39}$ U.S. Department of Labor and U.S. Department of Labor Statistics, 100 Years of U.S. Consumer Spending: Data for the Nation, New York City, and Boston, 2006, accessed November 23, 2016, http://www.bls.gov/opub/uscs/1901.pdf

${ }^{40}$ United States Census Bureau, Statistical Abstract of the United States: 1901, "Percentage of Native and Foreign Born of Total Population, by States and Territories, Arranged Geographically for 1890 and 1900" No. 7, accessed November 23, 2016. http://www2.census.gov/library/publications/1902/compendia/statab/24ed/1901-02.pdf

${ }^{41}$ CCNY Records. (Bayonne, NJ, Carnegie Library Correspondence, Microfilm No. 2).
} 

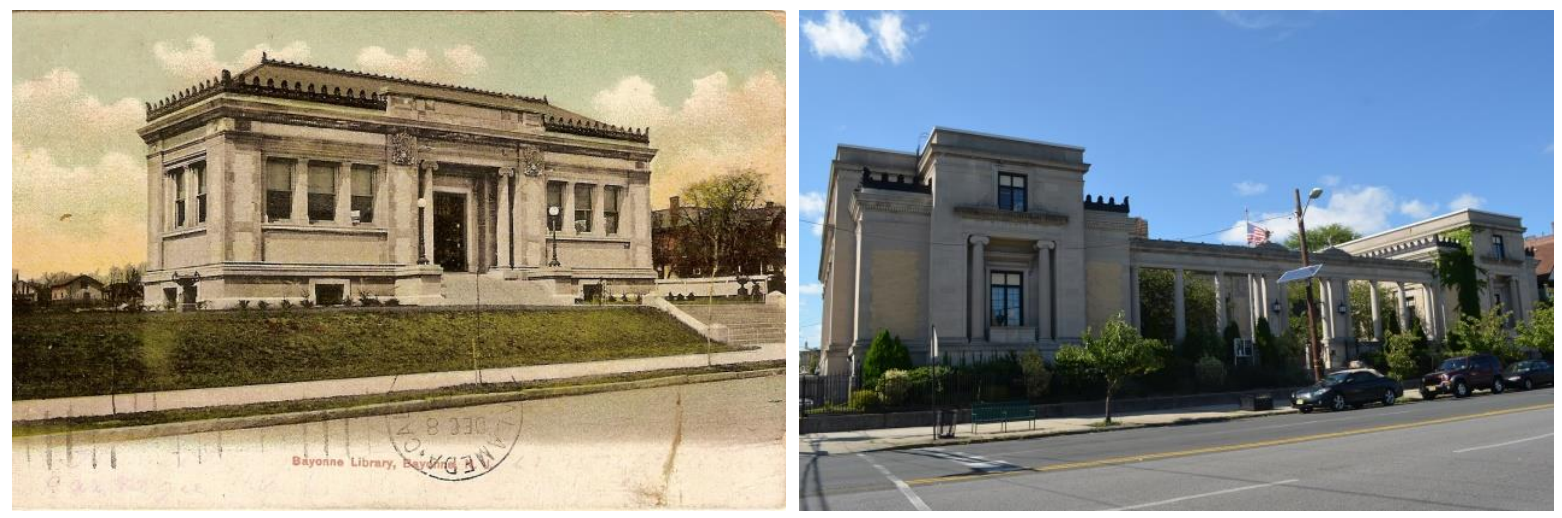

Carnegie Library, Bayonne, N.J. Postcard circa 1904 and photograph, 2014, from author's collection.

On January 27, 1913 a request was made for funding in order to expand the Bayonne library, whose stacks were filled to capacity. A report of Bayonne's 1912 circulation statistics provided a detailed account of the usage of the 31,407 volumes and an indication of exactly what patrons were reading. Total circulation among the 8,927 patrons was 196,228 volumes, of which fiction represented seventy-eight percent of books circulated, fifty-six percent being adult fiction and twenty-two percent juvenile fiction. Furthermore, Trustee President T.J. Parker remarked that in support of the large working class population, the library offered a unique collection of technical materials, "By the use of these books, the artisan, the mechanic, the boy or young man who is fitting himself for a vocation in life has been immensely benefitted." 42 Carnegie provided Bayonne with an additional \$30,000 for expansion of the main library in May 1913.

Perth Amboy was another major city with a large manufacturing base. Correspondence indicated that money was not available for a library building due to the curtailment of city expenditures in order to recover from a loss of $\$ 140,000$ sustained through the failure of the Middlesex County Bank in $1899 .{ }^{43}$ The city initially received a \$20,000 grant in March 1901, but

\footnotetext{
${ }^{42}$ T. J. Parker to Carnegie, 21 February 1913. CCNY Records. (Bayonne, NJ, Carnegie Library Correspondence, Microfilm No. 2).

${ }^{43}$ William Hesser to Carnegie, 25 February 1901. CCNY Records. (Perth Amboy, NJ, Carnegie Library Correspondence, Microfilm No. 24).
} 
in May 1914 another request for funds was made to expand the Perth Amboy library to meet the needs of a population that had doubled in size. F. L. Antisell, President of the Board of Trustees, described Perth Amboy as a "Works" city with a large foreign population who used the library as an educational institution bridging the gap between their native language and English through standard books printed in foreign languages, facilitating self-education. In many ways this epitomized Andrew Carnegie's philanthropic goal of improving the status of the working class. Perth Amboy also had a significant number of technical men working as chemists, engineers, and metallurgists, to whom a technical library was essential. The library developed a collection of commercial catalogs from U.S. and European manufacturers, as well as trade directories to assist technical workers. ${ }^{44}$ James Bertram met personally with Antisell and the architect to review plans for the addition and ultimately offered $\$ 30,000$ to expand the library building with additional reading rooms.
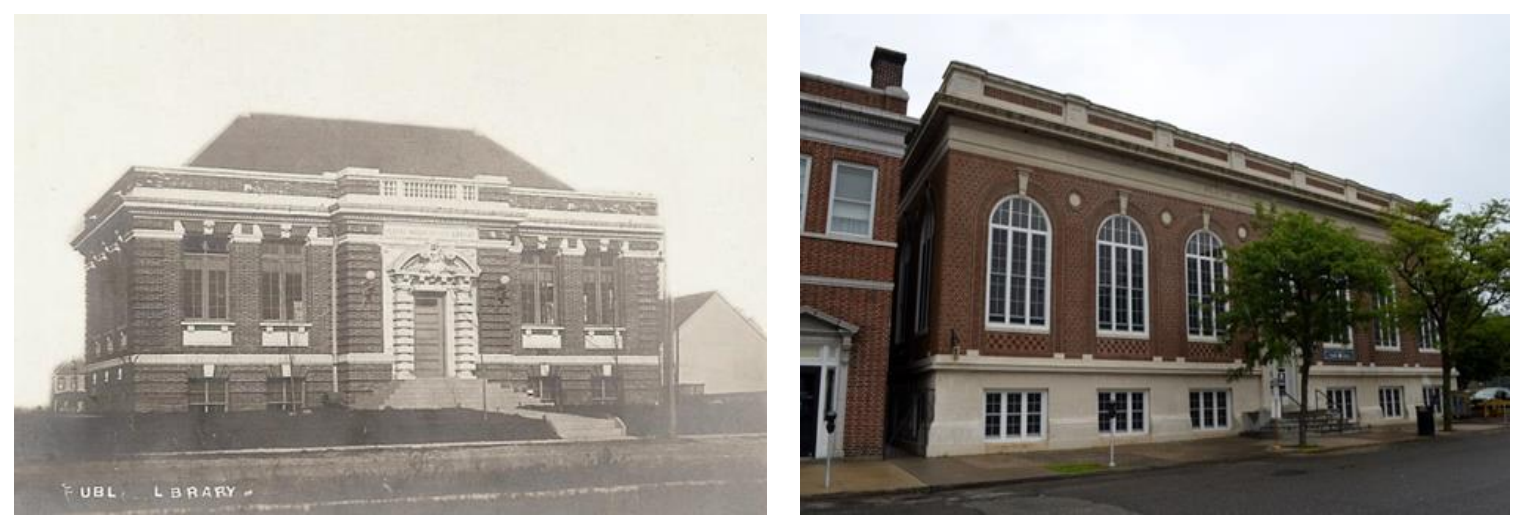

Carnegie Library, Perth Amboy, N.J. Postcard circa 1905 and photograph, 2014, from author's collection.

New Brunswick mayor George Viehmann described the population of the city in 1900 as slightly in excess of 20,000, the majority of whom were people working in factories. He explained

\footnotetext{
${ }^{44}$ F. L. Antisell, President, Perth Amboy Library Board of Trustees to Ferd Garretson, mayor of Perth Amboy.
} CCNY Records. (Perth Amboy, NJ, Carnegie Library Correspondence, Microfilm No. 24). 
that the few wealthy citizens seemed to lack public spirit and progress, while the working classes were liberal and progressive but were unable to raise the money necessary to build a proper library. Viehmann further explained that the residents lacked discretionary income and should not be expected to fund a library, "the laboring population cannot well afford to deny themselves and their families the comforts and protection for the future which requires the use and saving of all their earnings. $" 45$ The city was initially offered $\$ 50,000$ in 1902 to build a new library to house the 19,500 volume collection located in a framed residential structure. The new library building was designed by architect George K. Parsell, and had distinctive fan-shaped stacks to accommodate the collection. In 1909, an additional $\$ 2,500$ was received from CCNY to double the capacity by putting a glass floor over the stacks and duplicating the stacks on a second level.
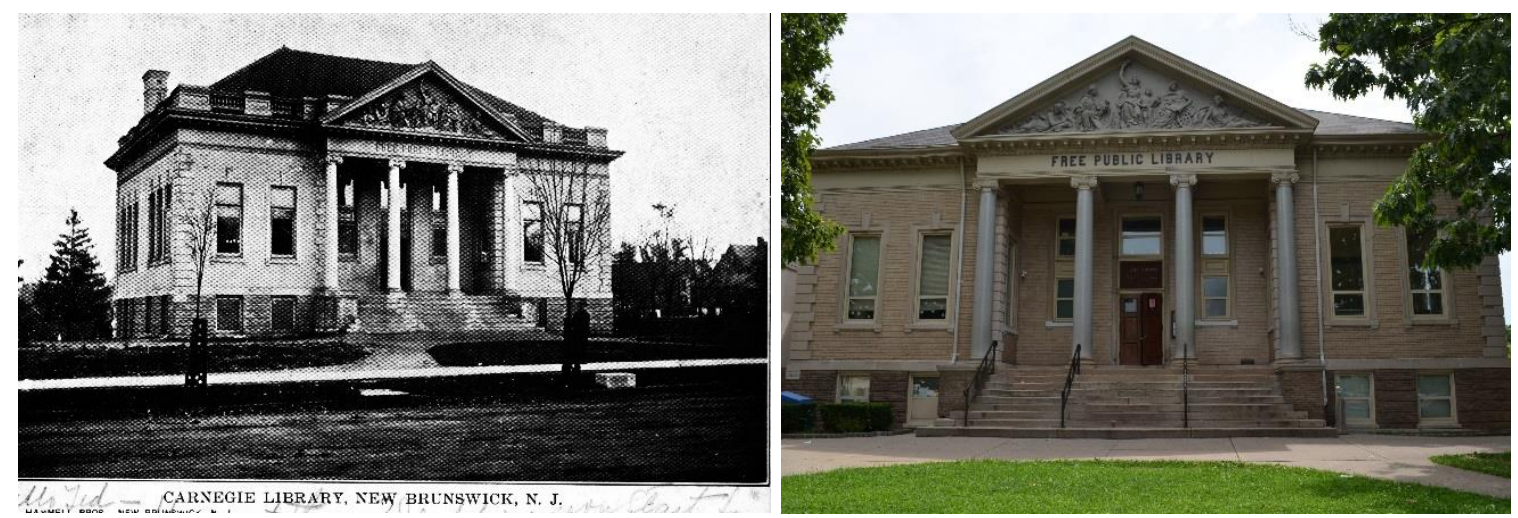

\section{Carnegie Library, New Brunswick, N.J. Postcard circa 1905 and photograph, 2014, from author's collection.}

In February 1904, John Davidson described the citizens of Kearny as chiefly mill workers employed by the Clarks and Marshalls cotton and linen thread mills, the Nairn Linoleum, Arlington Celluloid works, and other small establishments and factories in the nearby cities of Harrison and Newark. He noted that the people were hardworking and industrious, with two-thirds of the population composed of Britishers, English, Scotch, and northern Irish. "They are people

\footnotetext{
${ }^{45}$ George Viehmann to Carnegie, 25 February 1902. CCNY Records. (New Brunswick, NJ, Carnegie Library Correspondence, Microfilm No. 21).
} 
who appreciate the value of reading and education as is evidenced by their earnest and liberal support of the public schools." He proudly added that due to the high quality of education in the public schools, many graduates entered college without the need for further examinations. ${ }^{46}$

A number of smaller industrial towns with working class populations also sought funding for Carnegie libraries. The community of West Hoboken applied for funding on January 18, 1902 to replace their 4,000 book public library that was well patronized by working classes. ${ }^{47}$ In a letter to Andrew Carnegie, Percy Jackson described the 7,000 people living in Belleville as chiefly workmen in the factories and clerks employed in banks and stores in the City of New York or in the City of Newark, with less than ten citizens with income of over $\$ 5,000 .^{48}$
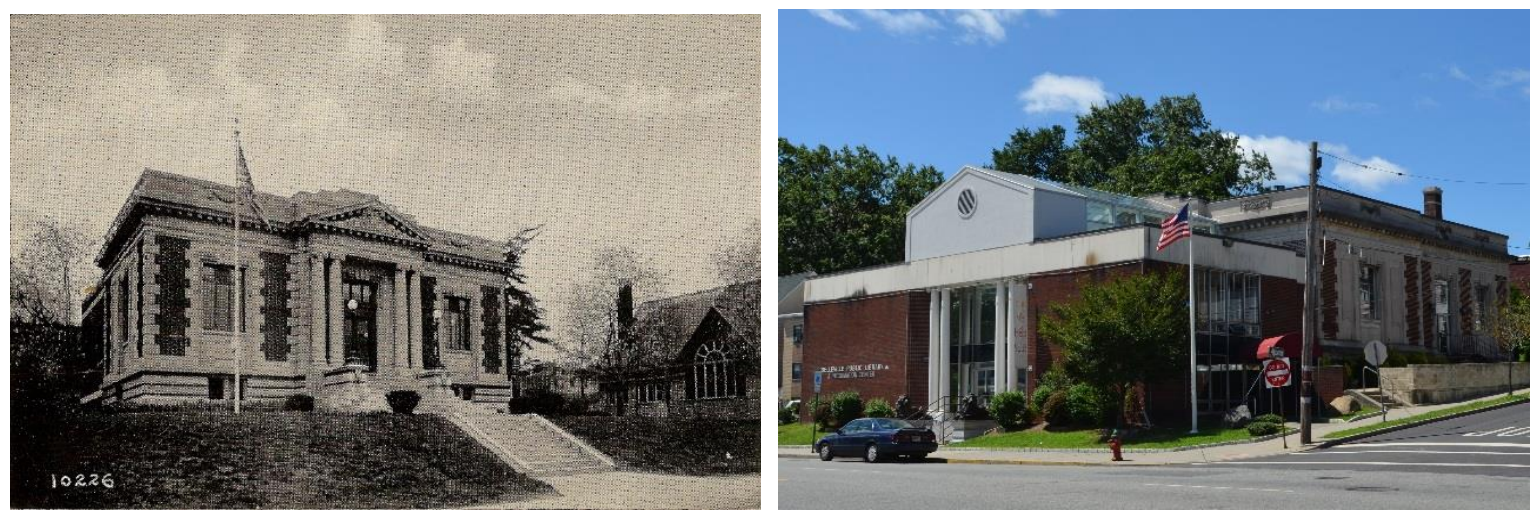

Carnegie Library, Belleville, N.J. Postcard circa 1910 and photograph, 2014, from author's collection.

Edgewater was another of the small towns, located just across the Hudson River from New York City, composed of neighborhoods of commuters and factory workers. Dr. L.M. Hubbard, President of the Board of Trustees, described the community of 2,655, "There is no family in the town which could be classed as wealthy. On the other hand, there are almost none who are poverty stricken. The majority are prosperous working people. There is a comparatively small commuting

\footnotetext{
${ }^{46}$ John Davidson to Carnegie, 20 February 1904. CCNY Records. (Kearny, NJ, Carnegie Library Correspondence, Microfilm No. 15).

${ }^{47}$ CCNY Records. (West Hoboken, NJ, Carnegie Library Correspondence, Microfilm No. 34).

${ }^{48}$ Percy Jackson to Carnegie, 28 October 1904. CCNY Records. (Belleville, NJ, Carnegie Library Correspondence, Microfilm No. 3).
} 
class and a large factory and local business element." ${ }^{49}$ The chief industries in Edgewater were concentrated in 10 large factories involved with sugar refining, manufacturing of corn products, printing inks, chemicals, pearline, linseed and petroleum oil products, roofing and paving materials, and yarn and wool dyeing. ${ }^{50}$

Correspondence between Edgewater and Carnegie included details regarding the 3,755 book collection housed in one overcrowded room located in the Borough Hall. The library had a circulation of 14,528 in 1914, with 8,597 adult and 5,931 juvenile loans, and 12,485 reading room visits. A special report was submitted by Edgewater to further explain the need for a new library in order to sustain the robust set of services initiated when the library was first opened in 1911, which included: free public lectures, four traveling libraries which visited the public schools, inauguration of educational motion picture entertainment, circulation of high class music, and story-telling hours for young children by a member of the Story-telling Course of Study at Teachers College, New York. ${ }^{51}$ In order to promote the new Carnegie building completed in 1916, a letter was sent to all community residents touting the library as a source of civic pride and a vital force in the life of the town. A card was enclosed providing full library privileges to borrow books and magazines that would help citizens with their work, music for the piano for leisure hours, and mounted pictures for home enjoyment. ${ }^{52}$

\section{Metropolitan Suburbs}

Due to its proximity to the New York and Philadelphia metropolitan areas, New Jersey experienced a heavy influx of migrants moving to the state. Many workers commuted by ferry

\footnotetext{
${ }^{49}$ Dr. L. M. Hubbard to Carnegie, 9 July 1913. CCNY Records. (Edgewater, NJ, Carnegie Library Correspondence, Microfilm No. 3).

${ }^{50}$ CCNY Records. (Edgewater, NJ, Carnegie Library Correspondence, Microfilm No. 9).

${ }^{51}$ Daniel Higgins to R. A. Franks, Treasurer CCNY, 1 July 1915. CCNY Records. (Edgewater, NJ, Carnegie Library Correspondence, Microfilm No. 9).

52 "Edgewater," New Jersey Library Bulletin 6, no.2 (January, 1917): 3.
} 
across the Hudson River to jobs in New York City. The completion of the Hudson \& Manhattan Railroad between Newark and New York further accelerated the growth of New Jersey's suburban towns. ${ }^{53}$ Applications for Carnegie library funding submitted by these towns frequently mentioned the progressive nature of the residents and strong support of education. As a result, they sought to build libraries that would provide supplemental reading material for their schoolchildren and townspeople.

Finding a location for the Carnegie library close to its public schools was a priority for the community of Montclair. The initially proposed site for the main library was changed to a superior location at the corner of Church Street and Valley Road, facing the public school. Mr. Anderson of Pittsburgh was selected to design the building, which was completed for $\$ 40,000$. The Bellevue Branch Library in Montclair was partially funded by Carnegie.

The Westfield application was prepared by Lloyd Thompson, Town Clerk, noting a population of 5,000. The town had a library of 4,500 books in two rented rooms on the ground floor of a brick building on the town's principal street and lot for a new library was secured for $\$ 4,000$. Carnegie offered $\$ 10,000$ on December 30, 1904. Work commenced on the building in 1906, but requests for additional funding were made shortly thereafter in 1907 and 1909, to increase the amount to $\$ 15,000$ in order to allow an addition to the back for a children's room since the accommodation for children was only a half dozen seats, but there were often twenty to twentyfive children in their corner. The additional \$5,000 was promised on March 27, 1909. ${ }^{54}$

\footnotetext{
${ }^{53}$ Joseph G. Bilby, James M. Madden, and Harry Ziegler, 350 Years of New Jersey History from Stuyvesant to Sandy (Charleston, SC: History Press, 2014), 124.

${ }^{54}$ CCNY Records. (Westfield, NJ, Carnegie Library Correspondence, Microfilm No. 24).
} 
The 1902 Union Hill application completed by Joseph Young noted a population of 15,187 in 1900 and that the library of 5,683 books was located in the Town Hall with reading and reference rooms. The letter from Bertram on April 20, 1903 explained that the initial request was denied since the accommodation of the previous library was deemed sufficient and there was some confusion about the location of the town. However, on January 30, 1904, A. Riesenburger explained that Union Hill sought funding because the new school house did not have room to set aside for the public library. He also explained that Union was the business center for outlying communities whose combined population was estimated at 50,000.55 On February 5, 1904, Carnegie offered $\$ 25,000$ to erect a free public library.
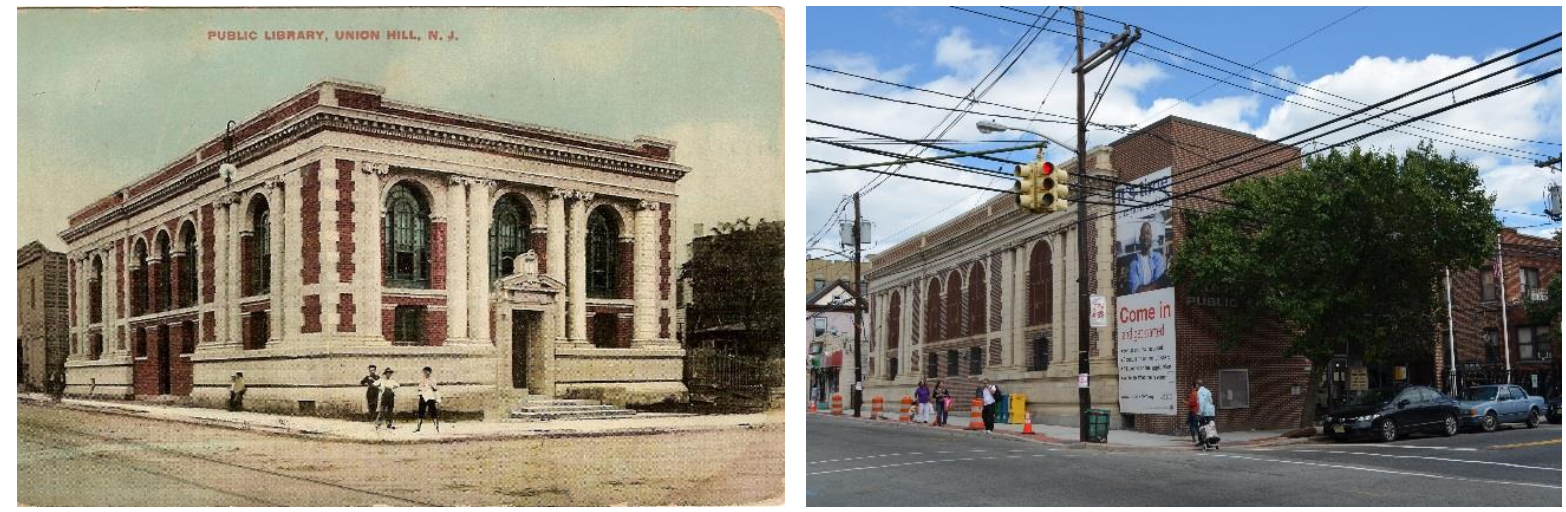

Carnegie Library, Union Hill, N.J. Postcard circa 1905 and photograph, 2014, from author's collection.

The application for Cranford was completed by Theodore V. W. Anthony, President of the Cranford Free Public Library Association on December 26, 1907. In a letter accompanying the application, Anthony gave a description of a typical suburban town during the Progressive era: "The present population is not far from 4,000. In every respect, it may be said without exaggeration, Cranford is a strong and progressive town, with fine schools and churches, and

\footnotetext{
${ }^{55}$ Riesenburger to Bertram, 30 January 1904. CCNY Records. (Union, NJ, Carnegie Library Correspondence, Microfilm No. 32).
} 
within the past two or three years decided evidence of improvement and growth have been noted." $" 56$

In a letter written on behalf of the Free Public Library at Summit Board of Trustees, Russell Hinman described Summit as a suburban city with a population of 7,000-8,000, composed chiefly of the families of men doing business in New York and Newark, and of local tradesmen and mechanics. The only major business in the town was a silk factory and the Commonwealth Water \& Light Company. ${ }^{57}$

In his appeal for building funding, mayor Randolph of Plainfield expressed a desire to consolidate several libraries into one easily accessible building, explaining that the library had been maintained for many years in eight branch locations, at the five public schools, the two principle machine shops, and the Young Men's Christian Association. ${ }^{58}$ The town of Plainfield experienced complications with the grant application and an initial rejection of proposed building plans for their Carnegie library. After a personal meeting with Bertram, plans were simplified and it was decided that the library would serve both Plainfield (22,000 population) and North Plainfield $(6,000)$ due to the services they already had in common such as a railway station, waterworks, light and power supply, and teachers and pupils in the educational system. ${ }^{59}$

Two other suburban communities received funding in 1913, Englewood and Nutley. In a January 22, 1913 letter to the CCNY, Thomas B. Kerr described Englewood, a town located on the western slope of the Palisades along the Hudson River, as a typical suburban population made up of families of persons engaged in business in New York, as well as local supply men,

\footnotetext{
${ }^{56}$ Theodore V. W. Anthony to Carnegie, 26 December 1907. CCNY Records. (Cranford, NJ, Carnegie Library Correspondence, Microfilm No. 7).

${ }^{57}$ Russell Hinman to Carnegie, 11 May 1908. CCNY Records. (Summit, NJ, Carnegie Library Correspondence, Microfilm No. 30).

${ }^{58}$ Leonard Waldo to Carnegie, 3 February 1911. CCNY Records. (Plainfield, NJ, Carnegie Library Correspondence, Microfilm No. 25).

${ }^{59}$ CCNY Records. (Plainfield, NJ, Carnegie Library Correspondence, Microfilm No. 25).
} 
mechanics, and laborers. ${ }^{60}$ According to William J. Kinsley, "Nutley is a residential commuting community made up largely of young married people and a larger population of children. The town has a very large reading population in proportion to the total population.",61

In 1915, Myrton A Bryant described the community of Collingswood in the southern part of New Jersey as strictly residential, where about seventy-five percent of the people own their own homes or are trying to pay for them. "We have no men of wealth, neither do we have any paupers. We are distinctly a reading community, and while most of our homes have some good books, by far the greater number of our people welcome the opportunities for wider reading and study afforded by the Collingswood Public Library."62

\section{Resort Towns}

Several Carnegie libraries were erected in New Jersey’s resort towns (Atlantic City, Avonby-the-Sea, Belmar, and Long Branch). A unique situation transpired in these communities. The population of the resort towns fluctuated dramatically between permanent year-round residents, and the influx of tourists who arrived for summer vacations. However, both winter and summer residents had need of a public library.

Atlantic City was the largest of the resort towns, with a resident population of more than 27,000 in 1900 plus summer vacationers. Alfred M. Heston, Secretary of the Board of Trustees, described Atlantic City as a progressive city, similar to Newark, Jersey City, and Paterson. ${ }^{63}$ Subsequent to receiving funding of \$71,075, architect Albert Randolph Ross won the city’s design

\footnotetext{
60 Thomas B. Kerr to Carnegie, 22 January 1913. CCNY Records. (Englewood, NJ, Carnegie Library Correspondence, Microfilm No. 10).

${ }^{61}$ William J. Kinsley to Bertram, 13 March 1913. CCNY Records. (Nutley, NJ, Carnegie Library Correspondence, Microfilm No. 22).

${ }^{62}$ Myrton A. Bryant to CCNY, 7 December 1915. CCNY Records. (Collingswood, NJ, Carnegie Library Correspondence, Microfilm No. 6).

63 Alfred M. Heston to Carnegie, 10 January 1903. CCNY Records. (Atlantic City, NJ, Carnegie Library Correspondence, Microfilm No. 2).
} 
competition to build a three story, 9,000 square foot library in a classical design in marble and granite, with iron wrought staircases and terrazzo floors. The building, located just one block from the Atlantic City Boardwalk, was dedicated on January 2, 1905.

On the exterior of the Atlantic City Public Library building, the statement "Open to All" welcomed the public. To encourage reading, during “Good Book Week," December $4^{\text {th }}-9^{\text {th }}, 1916$ special library posters were displayed in street cars, stores, and schools. Children were also asked to make a list of their favorite books to recommend to friends, and hundreds of these lists were posted on the library's bulletin boards. The library achieved its goal of heavy usage by both school children for after-school programs and resort children in Atlantic City for the summer. The patronage and check out of books was so high that library administration was forced to limit the check out to one book per week. ${ }^{64}$
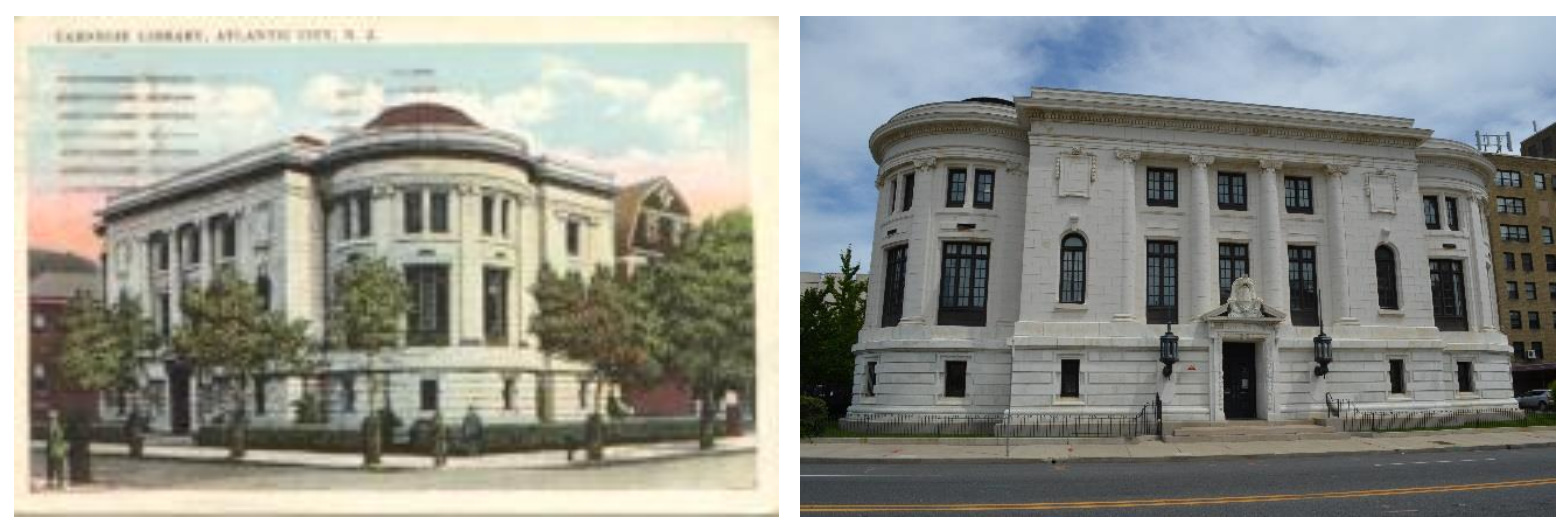

Carnegie Library, Atlantic City, N.J. Postcard circa 1929 and photograph, 2014, from author's collection.

Carnegie libraries were also built further north along the Jersey shore in the neighboring resort towns of Belmar and Avon-by-the-Sea. A handwritten letter from Miss Philips, who summered in Belmar with her sister, initiated correspondence with Carnegie in April 1912,

64 “Atlantic City,” New Jersey Library Bulletin 6, no.2 (January 1917): 3. 
describing the necessity for a library building to meet the needs of the entire Belmar community. ${ }^{65}$ The official application submitted by William B. Bamford on December 15, 1913 indicated that Belmar's population was 1,433 according to the 1910 U.S. Census. During the summer, the population with resort visitors swelled to 10,000, according to the N.J. State Board of Health. Belmar received a total of $\$ 13,000$ to build the library designed by architect Edward Tilton that featured a large room on the main floor divided into an adult and children's section, and a small lecture room in the basement. ${ }^{66}$

Since the population of Avon-by-the-Sea was below the 1,000 people normally required by Carnegie for funding, additional support for the application was sought from the New Jersey PLC. In a February 1915 letter, Mr. Buchanan, secretary of the PLC, explained that although the state census indicated a winter population of 707 for Avon, town officials and realtors estimated that the summer population was around 4,000. Avon's request for funding was successful, and upon receiving word that the Carnegie Corporation would provide $\$ 5,000$ to fund the library, President of the Library Board Miss Penrose wrote, "We are grateful. The starved lives in little Avon are now assured of practical mental food with adequate housing and the people will increasingly avail themselves of the benefits, the summer people too." 67

In his oration at the laying of the cornerstone for the library, Naval Officer H. Otto Wittpenn confirmed strong readership among the community citing statistics presented at the 1916 summer convention of the state librarians in Atlantic City, "the borough has the highest percentage of readers of all towns and cities in the state. ${ }^{68}$ In a handwritten letter dated August 18, 1919,

\footnotetext{
${ }^{65}$ Miss Philips to Carnegie, 17 April 1912. CCNY Records. (Belmar, NJ, Carnegie Library Correspondence, Microfilm No. 3).

${ }^{66}$ CCNY Records. (Belmar, NJ, Carnegie Library Correspondence, Microfilm No. 3).

${ }^{67}$ Valeria F. Penrose to Bertram, 17 May 1916. CCNY Records. (Avon, NJ, Carnegie Library Correspondence, Microfilm No. 2).

68 “To Lay Stone at Avon for Smallest Carnegie Library,” Newark (N.J.) News, September 21 1916. CCNY Records. (Avon, NJ, Carnegie Library Correspondence, Microfilm No. 2).
} 
Miss Penrose wrote, "The three years we have been in our charming little building have proven most conclusively the wonderful advantage and benefits it has seen and winter and summer people continue to express their appreciation." 69
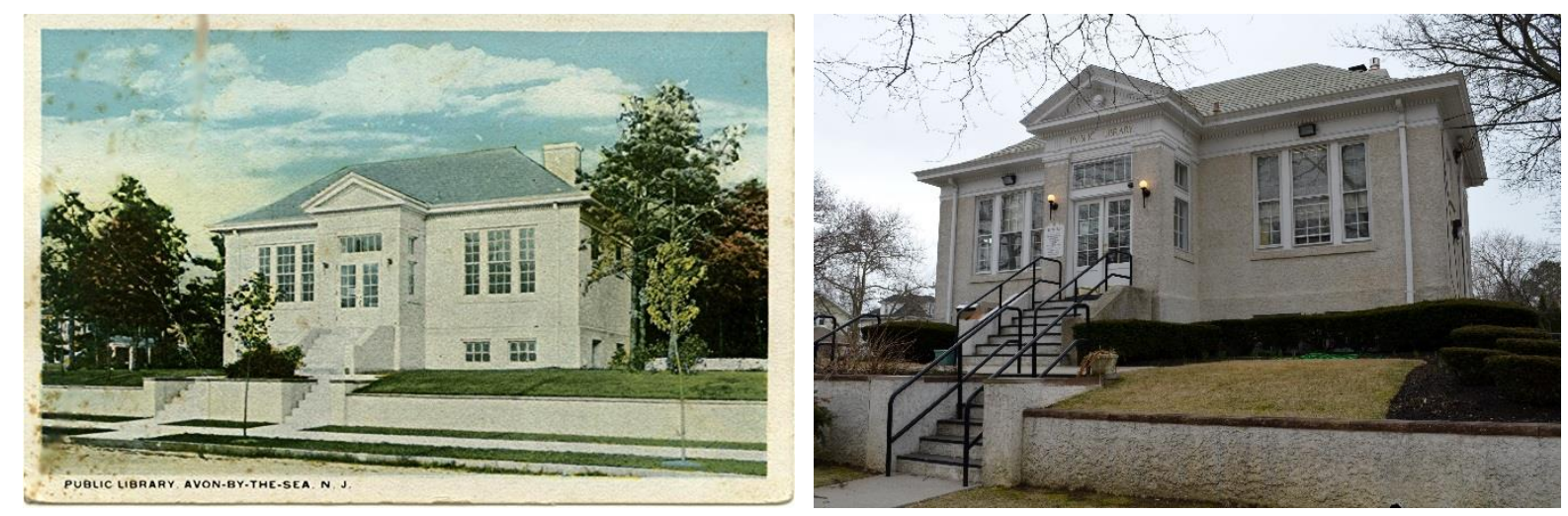

Avon-by-the-Sea, N.J. Postcard circa 1917, courtesy of Avon-By-the-Sea Library and photograph, 2014, from author's collection.

Founded in 1878, the East Long Branch Reading Room and Library Association successfully opened public libraries in Long Branch and the Elberon section of town. Both libraries played an important role in providing reading material for children of the community. ${ }^{70}$ The 1906 PLC report noted that the Elberon Public Library had been made free, and as it was not kept open every day, the teachers of the community were furnished with keys so that they had access to the collection at any time. ${ }^{71}$ The Library Association paid all the expenses to maintain the free libraries, including rent, coal and light bills, and library salaries by raising money with card parties, suppers, and entertainment. While the Library Association did not initially support applying for Carnegie funding, there was a change of opinion in 1916. The Library Association's Free Reading Room was so successful that there was often not enough space for all the boys and girls who wanted to use the books and magazines, serving as conclusive evidence that the facilities were

\footnotetext{
${ }^{69}$ Valeria F. Penrose to Carnegie, 18 August 1919. CCNY Records. (Avon, NJ, Carnegie Library Correspondence, Microfilm No. 2).

${ }^{70}$ CCNY Records. (Long Branch, NJ, Carnegie Library Correspondence, Microfilm No. 17).

${ }^{71}$ Public Library Commission of New Jersey Reports. Seventh Report of the Public Library Commission of the State of New Jersey. (Trenton, NJ: John J. Murphy Pub. Co., 1906), 6.
} 
inadequate and a new library was needed. Library Hall was sold for $\$ 16,000$ and the Association acquired the Slocum homestead adjacent to City Hall for a larger library which was later deeded to the city for the Carnegie Library. Long Branch mayor Marshall Woolley submitted an application to Carnegie, and received $\$ 30,000$ for a new building on February $3,2017 .{ }^{72}$ According to newspaper reports, the library opened on November 16, 1920 and was attended by 40-50 people. In the final remarks of the opening ceremony, E. Randolph Slocum noted that schools were the salvation of the country and next to schools in importance to the education of people were libraries. $^{73}$

\section{Effects of World War I}

During the final years of the Carnegie library program, Bertram required that all communities start construction within two years of receiving a grant or forfeit the money. Several New Jersey communities that applied for Carnegie funding after 1915 encountered delays in construction due to material and labor shortages resulting from the United States' entry into World War I. The resort town of Long Branch asked for an extension of two years in which to build the library, noting, "Giving to the high cost of materials and labor and as a patriotic duty it is manifestly not desirable to take labor from government work at this time for the purpose of building our Library.",74

Similarly, Verona encountered several delays in the erection of their library. A formal application was submitted by Mayor David Slayback of Verona in 1916 when the space used for the library in the high school was needed for instruction. The Library Trustees had expected to

\footnotetext{
72 Ibid.

73 "New Library Building is Formally Dedicated with Simple Ceremonies," Long Branch Daily Record, November $17,1920$.

${ }^{74}$ Marshall Woolley to Carnegie, 15 February 1918. CCNY Records. (Long Branch, NJ, Carnegie Library Correspondence, Microfilm No. 17).
} 
finance a new library building, but due to the urgent need for a facility contacted Carnegie for funding. An offer of $\$ 10,000$ was made on March 31, 1916. In 1917, due to the high costs of labor and materials experienced during the war years, the Library Trustees decided to temporarily suspend plans for the new public library building, hoping for an improvement in conditions. By 1920 labor conditions had improved, but the amount of funding required for the library had increased. The borough experienced further delays while they sought a modification in state legislation in order to raise additional money through bonds. The legislative changes took a significant time, and with the help of the PLC, Verona asked Carnegie for and was granted an extension in the time allowed to start construction. In 1921, funding was solidified, but a decision was made to change the location to a new grouping of civic buildings and adjustments to the building plans were necessary. Delays in construction were again encountered in September 1922, when the shipment of bricks was interrupted. The building was officially the last of the New Jersey Carnegie libraries to be completed and opened on the evening of September $7,1923 .{ }^{75}$

Mrs. J. Hosford Smith, Vice Chairman Library Committee of the Women's Club, sent the initial letter of inquiry for Little Falls to CCNY. The collection of 2,500 books was housed in rented rooms in the basement of a brownstone house occupied by Seugling Appliance Store. In January 1917, assistance was sought from Mrs. Edna Pratt of the NJ Library Commission to support the application for Carnegie funding because of the small size of the town of Little Falls and limited financial support available through taxation. On April 3, 1917, Carnegie offered $\$ 10,000$. Building plans were developed by H.P. Crosby and work began on the building in September 1917, but labor shortages and rising prices delayed the completion of the library until September $7,1918 .^{76}$

\footnotetext{
${ }^{75}$ CCNY Records. (Verona, NJ, Carnegie Library Correspondence, Microfilm No. 32).

${ }^{76}$ CCNY Records. (Little Falls, NJ, Carnegie Library Correspondence, Microfilm No. 17).
} 
When Lakewood was approved for funding on February 3, 1917, work on the building was initiated as soon as the plans by architect Hobart Walker were approved by Bertram since the Lakewood Board of Trustees had funds set aside for books that had to be expended prior to the Carnegie funding being available. A letter dated January 14, 1918 announced that the building was complete and ready for use, but that a lack of coal resulted in occupying the old quarters for a couple of additional weeks, reading, "If we had not commenced the work before the war, we would not have considered it wise to build during the high-priced war time period. But by hard work we were able to secure the money necessary to supplement your donation and carry the work to completion free of debt.",77

While World War I delayed building construction in a several communities, other Carnegie libraries actively participated in war efforts. The basement of the East Orange library served as a registration site for the military. In 1917, the PLC asked that all New Jersey libraries offer free access to all soldiers stationed nearby. The Edgewater library appropriated three months of regular book purchases to buy books that would help prepare soldiers for war, while the Lakewood library purchased specialized books for surgeons, nurses, and soldiers located in a neighboring military hospital and nurses' station treating injured war veterans. Several Carnegie libraries (Belmar, Cranford, East Orange, Edgewater, Englewood, and Perth Amboy) hosted home nursing and first aid classes, Red Cross classes and meetings, and cooking and canning demonstrations. In addition, townspeople in Atlantic City, Freehold and East Orange collected books, magazines, and newspapers for soldiers. ${ }^{78}$

\footnotetext{
${ }^{77}$ Sherwood B. Ferris to Carnegie, 14 January 1918. CCNY Records. (Lakewood, NJ, Carnegie Library Correspondence, Microfilm No. 16).

78 "Libraries and War Service," New Jersey Library Bulletin 6, no.4 (July 1917): 1-4.
} 


\section{Impact of Carnegie Libraries on Communities}

As described in this manuscript, Carnegie public libraries have played a significant role in the New Jersey communities in which they were established. Carnegie funding enabled communities to erect library buildings and move their book collections housed temporarily in rented rooms or private homes into new, dedicated facilities. The "Carnegie libraries were selfconsciously designed to encourage a process of social and cultural transformation." 79 For much of the general population, free public libraries offered townspeople their first opportunity to browse books and magazine collections on a broad range of topics. Centrally located, the libraries became a centerpiece of the community and were open to all - men, women, and children. In addition to the circulating collections, library patrons were presented with lectures on topics of interest and offered a meeting place for local clubs. Factory and shop workers had opportunities for selfeducation to improve their status in life, realizing the philanthropic goals that Andrew Carnegie had envisioned. Immigrant families were able to improve their language and literacy skills. Furthermore, the libraries now provided dedicated children's rooms for reading and collaborated with local school teachers, supplementing classroom instruction presented in the newly mandated public education system.

As of 2017, almost half of New Jersey's Carnegie libraries remain in their original buildings and still function as public libraries. In many towns there is a sentimental value to retain the original Carnegie buildings, despite the costly repairs and renovations necessary to upgrade facilities. The century-old buildings have required extensive remodeling to improve heating, cooling, and lighting, as well as providing handicap access to the buildings. Although some of the Carnegie libraries have retained their original footprint while undergoing interior renovations,

\footnotetext{
${ }^{79}$ Van Slyck, Free to All, 201.
} 
many have expanded with additions in order to serve their growing communities. In some cases, expansion was not possible as property sites were of insufficient size and the Carnegie libraries were either razed for new buildings, or property was purchased to build an entirely new public library. Several of the Carnegie buildings have survived due to adaptive reuse and currently serve as senior citizen centers, cultural centers, and office space. ${ }^{80}$

A great deal has changed in terms of a typical library user from the early 1900s to the 2000s. While public libraries still offer books and special programming, there is a growing emphasis on technology resources to help patrons tap the broader range of information accessible digitally. The "Libraries=Education" movement is currently gaining momentum in repositioning libraries as educational institutions delivering equal opportunity in education for all, reclaiming the original twentieth century message and Carnegie's vision of self-directed education. ${ }^{81}$ As the Carnegie libraries celebrate their centennial anniversaries, their ability to transform themselves into institutions that provide a full array of services their patrons require has allowed them to remain relevant, and continue to play a vital role in New Jersey communities.

Eleonora Dubicki is a reference and instruction librarian at Monmouth University. She has published two books and more than a dozen articles on topics in the field of library and information science. The primary focus of her research is on information literacy and informationseeking behaviors. She holds an undergraduate degree in American Studies from Douglass College and a MLS and MBA from Rutgers University.

\footnotetext{
${ }^{80}$ Hazard, New Jersey Monthly

${ }^{81}$ Valerie J. Gross, Libraries=Education, accessed May 2017, http://librarieseducation.org/
} 